\title{
DECODING CEO-SPEAK
}


This page intentionally left blank 


\section{DECODING CEO-SPEAK}

Russell Craig and Joel Amernic

UNIVERSITY OF TORONTO PRESS

Toronto Buffalo London 
Rotman-UTP Publishing

An imprint of University of Toronto Press

Toronto Buffalo London

utorontopress.com

University of Toronto Press 2021

All rights reserved. No part of this publication may be reproduced, stored in or introduced into a retrieval system, or transmitted in any form or by any means (electronic, mechanical, photocopying, recording, or otherwise) without the prior written permission of both the copyright owner and the above publisher of this book.

\section{Library and Archives Canada Cataloguing in Publication}

Title: Decoding CEO-speak / Russell Craig and Joel Amernic.

Names: Craig, Russell (Professor of business), author. | Amernic, Joel H.

(Joel Henry), 1946-author.

Description: Includes bibliographical references and index.

Identifiers: Canadiana (print) 20210193042 | Canadiana (ebook) 20210193093 |

ISBN 9781487505950 (cloth) | ISBN 9781487533021 (EPUB) |

ISBN 9781487533014 (PDF)

Subjects: LCSH: Chief executive officers - Language - Case studies. | LCSH:

Discourse analysis - Social aspects - Case studies. | LCSH: Corporate culture -

Case studies. | LCGFT: Case studies.

Classification: LCC HD30.3 .C73 2021 | DDC 306.44088/6584 - dc23

ISBN 978-1-4875-0595-0 (cloth)

ISBN 978-1-4875-3302-1 (EPUB)

ISBN 978-1-4875-3301-4 (PDF)

Printed in Canada

We acknowledge the financial support of the Government of Canada, the Canada Council for the Arts, and the Ontario Arts Council, an agency of the Government of Ontario, for our publishing activities. 
Russell Craig dedicates this book to his grandchildren Josephine, Patrick, Valerie, Alice, Samuel, and Dorothy.

Joel Amernic dedicates this book to his wife, Lilly, their children Heidi (Aaron) and David (Janice), and grandchildren Ben and Sarah, and Kayla and Ryan. 
This page intentionally left blank 